Article

\title{
Function and Form: Shifts in Modernist Architects' Design Thinking
}

\author{
Atli Magnus Seelow \\ Department of Architecture, Chalmers University of Technology, Sven Hultins Gata 6, 41296 Gothenburg, \\ Sweden; atli.seelow@chalmers.se; Tel.: +46-72-968-88-85 \\ Academic Editor: Marco Sosa
}

Received: 22 August 2016; Accepted: 3 November 2016; Published: 9 January 2017

\begin{abstract}
Since the so-called "type-debate" at the 1914 Werkbund Exhibition in Cologne-on individual versus standardized types-the discussion about turning Function into Form has been an important topic in Architectural Theory. The aim of this article is to trace the historic shifts in the relationship between Function and Form: First, how Functional Thinking was turned into an Art Form; this orginates in the Werkbund concept of artistic refinement of industrial production. Second, how Functional Analysis was applied to design and production processes, focused on certain aspects, such as economic management or floor plan design. Third, how Architectural Function was used as a social or political argument; this is of particular interest during the interwar years. A comparison of theses different aspects of the relationship between Function and Form reveals that it has undergone fundamental shifts-from Art to Science and Politics-that are tied to historic developments. It is interesting to note that this happens in a short period of time in the first half of the 20th Century. Looking at these historic shifts not only sheds new light on the creative process in Modern Architecture, this may also serve as a stepstone towards a new rethinking of Function and Form.
\end{abstract}

Keywords: Modern Architecture; functionalism; form; art; science; politics

\section{Introduction}

In 1907 the German Werkbund ('Deutscher Werkbund') was founded in Munich as an association of architects, artists and industrialists. The goal was to improve the quality of industrial mass production through a reconciliation (or partnership) of art and industry. The Werkbund's expansive motto "from sofa cushion to city planning" ('vom Sofakissen zum Städtebau') expressed its ambition not only of artistic refinement of industrial products, but also its ambition to establish of a "a modern style of our time"; this draws on Gottfried Semper's idea that a reform of architecture and urban planning has to originate from the arts and crafts. Two key issues discussed in the Werkbund were the role of the artist in the industrial design and production process as well as the question of translating Function into Form. A new concept of the artist as a "form-giver" ('Gestalter') instead of the artist as a craftsman was first put forward in 1908 at the annual Werkbund meeting in Munich and developed further in 1911 by Hermann Muthesius. Building on a long-standing aesthetic discourse he claimed that "Gestalt" ('form') should have primacy over function, material and technique in the design of industrial products. The question of translating Function into Form was then discussed in the so-called "type-debate" at the 1914 Werkbund Exhibition in Cologne. Hermann Muthesius proposed a concept of typification ('Typisierung'), i.e., establishing and refining "types" for mass production as Platonic Universals instead of reinventing new forms all the time-in order to raise the level of industrial products (to improve the competitiveness of German products in world markets) - or as he put it "to recover that universal significance [of architecture] which was characteristic of it in times of harmonious culture" ([1], pp. 204-22, here 205). 
This concept of Typification was met with harsh criticism i.a. by Henry van der Velde. Though not questioning the need for machine production or a unified culture, he argued that high quality relied on individual artistic freedom and experimentation; types were the result of an evolutionary artistic development. This argument was both seen as a debate between standardization versus individualism as well as a struggle between machine and handicraft production ([2], pp. 71-79; [3], pp. 57-81).

The question remained unresolved before World War One. Yet it laid the groundwork for a number of design strategies in the interwar years. These were built on different relationships between Function and Form and were influenced by aspects of the shifting historic context-Art, Science and finally Politics.

\section{Art}

The most influential experiments were undertaken at the Bauhaus, to begin with in Weimar, later in Dessau. In an intital phase following World War One an Expressionistic "Bauhütte"-mysticism was pursued-calling for a unity of all crafts and working toward "a new building of the future", as Walter Gropius proclaimed in the first Bauhaus Manifesto in 1919 ([4]; [5], pp. 173-236). Under the sobering artistic influence of the Dutch De Stijl group and Russian Constructivism, namely Theo van Doesburg and Lászlo Moholy-Nagy, a more objective approach was pursued from 1921 onwards. Seeking a unity of "Art and Technology" - the new motto of the Bauhaus-Walter Gropius picked up the German Werkbund's idea of artistic refinement in architecture and industrial mass production. In the seminal program “The Principles of Bauhaus Production" ('Die Grundsätze der Bauhausproduktion') from 1925, Walter Gropius outlined how this unity of Art and Technology, Form and Function should be applied in a design methodology: First an object's function or task should be analysed. Then it should be designed according to its functional nature using "modern production methods, constructions and materials" - to fulfill its purpose to be "durable, economical and 'beautiful"." Though this process may lead to "unusual and surprising forms", deviating from the conventional, it is-as Walter Gropius points out-necessary to create standard types for every-day use [6]. Yet Walter Gropius didn't elaborate on this quest for an object's nature or task. It is clear that he understood this process neither as a scientific empiric analysis nor as a phenomological method. In practice he saw an object's nature primarily in its "function" or "purpose" ('Zweck') or in other words he declared "the useful" "beautiful" - a commonplace in decorative arts following the British Arts \& Crafts movement. Thus the functional form is aestheticised-with the quest for an object's nature or task being turned into a search for ideal platonic geometry or, more precisely, translated into geometric forms. Hence most of the products designed at the Bauhaus under Walter Gropius were highly aesthetic objects of platonic geometry, as can easily be seen with Wilhelm Wagenfeld's lamps designed from 1923 on or Marcel Breuer's chairs after 1925. As a consequence emerged exactly what Walter Gropius initially set out to avoid: a Bauhaus style ([7], pp. 43-45).

A similar line of thought can be found with Le Corbusier who praised technological forms, the work of engineers and from 1921 onwards pursued a "machine à habiter". Yet regarding his architectural design process he invoked the poetics and lyrics of pure geometric forms and their play in light and shadow [8,9]. For explanation Le Corbusier referred to the famous French mathematician Henri Poincaré and the "solution élégante"-implying that his concepts are able to solve both technical and functional problems simultaneously with a nearly mathematically defined quality; but Poincaré conversely employed terms with strong aesthetic connotations-and very similar to those used by Le Corbusier-, such as harmony, symmetry, balance or order, to delineate an elegant solution to a mathematical problem [10].

In the 1920s and 1930s terms like "function", "purpose" or "nature" were used all the time to describe an objective analysis and design process-with architectural movements being labelled "functionalism" or "new objectivity" ('Neue Sachlichkeit'). Yet in practice the process of analyzing Function or Nature is cut short by resorting to ideal or aesthetic geometric forms. 


\section{Science}

Following World War One a number of industrial design and production methods developed in the US, such as assembly line production, as invented by Henry Ford, or scientific production management devised by Fredrick Winslow Taylor, were introduced in Europe. This shift in the relationship of Function and Form from broadly speaking Art to Science is historically motivated by the hope to solve the dire economic problems of the meagre postwar years, in particular in the Weimar Republic. A number of endeavours are undertaken to rationalize, i.e., to analyse and optimise on a scientific basis individual aspects of the design and building process, such as insolation, floor plan design or construction site management [11].

Particularly influential is again Walter Gropius-who claimed to be the "Ford of housing" ('Wohnford')—as well as his housing project Dessau-Törten (1926-1928) with its highly rationalized planning and construction process organised along the tracks of the construction site crane ([12], pp. 152-200; [13], pp. 9-28). Noteworthy are also Alexander Klein's studies to optimise floorplans based on movement patterns [14]; or the famous Frankfurt kitchen by Margarete Schütte-Lihotzky - a minimal kitchen optimised and typified along the lines of a railway dining car, designed for Ernst May's equally rationalised New Frankfurt housing projects $[15,16]$.

A special focus of the science based optimisation of design and construction processes was on optimising housing according to insolation diagrams. This was considered to have not only economic, but also hygienic and social benefits-up to the point of liberating housing and its inhabitants, providing "Light, air, opening" ('Licht, Luft, Öffnung'), as Sigfried Giedion wrote in his 1929 book Befreites Wohnen ('Liberated Housing') [17]. Architects strove to design housing to rescue people from lightless and disease-ridden backyards and to accommodate them in a healthy, liberated-and democratic fashion, i.e., not only to raise the average level of housing above the level of minimum dwelling, but also to provide everyone with the same amount of sunlight [18]. The most prominent discussion of this was at the second CIAM Conference 1929 on "The Minimum Dwelling" ('Die Wohnung für das Existenzminimum') that was hosted by Ernst May in Frankfurt ([19], pp. 35-71). Yet these idealistic functional and hygienic aspects based on scientific rationalisation served not only as arguments for democratic liberalisation, but were in the end also turned into arguments for economic optimisation, i.e., minimisation. If enough light and air got into the apartment, it could allegedly be easily reduced in size. The minimisation of living and working spaces combined with an ever-increasing optimisation of the design and production process gradually led to what Heinrich Klotz aptly named (at the symposium "Das Pathos des Funktionalismus" in Berlin in 1974) "building industry functionalism" ('Bauwirtschaftsfunktionalismus')—a mass-produced architecture without human design quality. As Heinrich Klotz argues the scientific rationalisation of design and production processes favours in the end the interests of financiers, i.e., banks and developers, and tends to neglect or even turn against the needs of the users. The conclusion is that the scientific rationalisation of turning function into form is inherently tied to political ideology [20].

The question, whom architecture in the end serves, split the Modern Movement politically in two groups: on the one hand a majority that conformed to the requirements of market capitalism and adopted the methods of scientific optimisation; on the other hand a small left wing that questioned the socio-economic conditions of society and wanted to change them.

\section{Politics}

Although many architects between the World Wars talked about building a new world and a new society, few reflected on ideology, politics or the economic framework of their work [21]. From the second half of the 1920s onwards many pioneers, some of them opportunists, adopt modern forms-white cubes, flat roof and ribbon windows-without seeking social change. One reason is that many renowned avant-garde architects, such as Le Corbusier, Ludwig Mies van der Rohe or Walter Gropius, were either unpolitical or only half-heartedly leaned towards Social Democracy. At most they wanted to contribute to a gradual evolutionary improvement of society in the sense of a 
"white socialism" - pacifying the proletarian masses—instead of radically challenging social structures. This socialdemocratic modernism was ridiculed by the philosopher Ernst Bloch for mistaking every sliding window as a preview of a future socialist paradise. But for a long time there is little debate with avantgarde architects on social or political activism and socially engaged modern architects for the most part receive little attention. One of the few prominent exceptions is Hannes Meyer's shift in the Bauhaus design methodology from "luxury production" ('Luxusbedarf') to "people's needs" ('Volksbedarf') ([22], pp. 51-57).

This changes after 1929 with the Great Depression. It is seen as a herald for the imminent collapse of the capitalist system. In this context the debate about the social and political role of architecture takes on a new meaning. In October 1929 Karel Teige initiates in Prague the group "Levá fronta kulturních pracovníku a intelektuálu" ('Left Front of Intellectuals and Cultural Workers') and in 1930 he gives a series of lectures at Hannes Meyer's Bauhaus "On the Sociology of Architecture" ('K sociologii architektury'), published the same year. He describes a program for a political and social architecture to transform society, i.e., to use architecture to revolutionise society-instead of mainting status-quo, i.e., building apartments to appease the proletariat as most social-democratic architects maintained. Functional architecture optimised along the lines of scientific rationalisation was-from the point of view of left functionalists-considered a "capitalist caricature" ([22]; [23], pp. 7-8, 17-18, 36-44).

These revolutionary ideas met little enthusiasm with the architectural establishment. When Karel Teige and a few other revolution-minded architects, such as Hannes Meyer, wanted to join CIAM, they were ushered out by the majority around Sigfried Giedion, Walter Gropius and Le Corbusier ([19], pp. 46-51; [23], p. 41). On an architectural level, one example for a new revolutionary building form to reflect a new social function are boarding houses that were modeled after communal houses ('Koldom') in the Soviet Union-to showcase a new way of life and anticipate a new socialist society. These houses were designed in a diagrammatic way to reflect their social function and equipped with numerous communal facilities and featured minimised individual living spaces [24].

Until 1930 modern constructivist architecture from the Soviet Union had been admired, but with the radical political debates in the course of the early 1930s it was more and more considered to be "unsavory red" [25]. Thus left functionalism never really caught on in Western Europe. Exhibitions, such as the Proletarian Building Exhibition ('Proletarische Bauausstellung') organized by the Collective for socialist Housing ('Kollektiv für sozialistisches Wohnen') in Berlin in 1931, never gained much attention and in some cases they were even shut down by the Police and banned. The authorities had figured out that these exhibitions were not only about architecture, but about revolution ([7], pp. 54-56).

In the early 1930s a number of radical architects, among them Hannes Meyer, emigrated to the Soviet Union, as construction had come to a standstill in the Great Depression. But they didn't enjoy much success [25]. Soon after, in 1932, Modern Architecture was abolished in the Soviet Union. Josef Stalin rejected any form of Internationalism or Cosmopolitism after the competition for the Palace of the Soviets and condemned Modern Architecture as Formalism. He prescribed Social Realism, so instead of communal houses historicist palaces were built for the proletariat [26].

In Western Europe Modernism was in most cases banned by the new dictatorships, only in Italy it was taken in the regime's service. With the emigration of leading protagonists of the Modern Movement to the Anglo-saxon countries the progressive social aspect of Modern Architecture was lost. As early as 1934 Walter Gropius-just after emigrating to England-wrote that it had been a mistake to try to bring Modern Architecture to the masses; in the future he wanted to convert the affluent to Modernism ([27], pp. 680-81) — exactly what he and Ludwig Mies van der Rohe and other emigrants later did in the United States.

\section{Epilogue}

Adolf Behne tried in his book Der moderne Zweckbau ('The Modern Functional Building') as early as 1923-though the book wasn't published until 1926-to categorize the different strands of Functional Thinking in Modern Architecture. He discriminiates between Organic Functionalism, Rationalism 
and Utilitarism: Organic Functionalism seeking the organic Performance Form; Rationalism searching for standards and types, as well as a concise, modern and elegant form; and Utilitarism pursuing the economic principle of labor- and time-saving [28].

Adolf Behne's terminology did unfortunately not catch on-neither on the European continent nor in the Nordic Countries. In particular in the Nordic Countries, Rationalism in Architecture was christened Functionalism, as the term insinuated more economic efficiency. This was considered an important "selling point" in the years of the Great Depression ([29], pp. 8-15). For instance Le Corbusier "persuaded" his friend Alberto Sartoris in 1932 to change the title of his book from Architettura razionale into Gli elementi dell'architettura funzionale [30]. Thus Functionalism with the abbreviation "Funkis" became both an aesthetic and political program for turning Sweden and later the other Nordic countries into the proverbial "Folkhem" ('people's home') welfare state ([31]; [32], pp. 58-72).

\section{Conclusions}

The comparison of the different aspects of the relationship between Function and Form reveals that it has undergone a number of fundamental shifts. These shifts in Modern Architects' creative process seem to be tied to broad historic developments. A seemingly simple equation as Louis Sullivan's "Form follows Function" or, in other words, how Modern Architects chose to translate Function into Form was in large parts dictated by the historic context.

It is also interesting to note that the major shifts in emphasis-from Art to Science and finally Politics-happened in a fairly short period of time in the first half of the 20th century. Yet this re-evaluation of values can be explained by the need to react to the rapid historic changes, i.e., need for artistic refinement of industrial mass-production, the necessity to employ scientific methods to overcome the economic problems after World War One and to participate in the radical political discussions of the 1930s.

It is fair to say that the major aspects of this relationship between Function and Form-Art, Science and Politics-established in the first half of the 20th century are still in use today as Design Strategies. So the question remains, if these suffice or if they are to serve as stepstones towards a new poetic rethinking of the relationship of Function and Form that contemporary values may require.

Conflicts of Interest: The authors declare no conflict of interest.

\section{References}

1. Posener, J. Die Anfänge des Funktionalismus: Von Arts und Crafts zum Deutschen Werkbund. Frankfurt am Main and Berlin: Bauwelt Fundamente, 1964.

2. Banham, R. Theory and Design in the First Machine Age. London: Architectural Press, 1960.

3. Campbell, J. The German Werkbund: The Politics of Reform in the Applied Arts. Princeton: Princeton University Press, 1978.

4. Gropius, W. Programm des Staatlichen Bauhauses in Dessau. Weimar, 1919; reprint Wingler, H.M. Das Bauhaus. 1919-1933 Weimar, Dessau, Berlin und die Nachfolge in Chicago seit 1937. Bramsche: Rasch, 1962, pp. 38-41.

5. Franciscono, M. Walter Gropius and the Creation of the Bauhaus in Weimar: The Ideals and Artistic Theories of Its Founding Years. Urbana: University of Illinois Press, 1971.

6. Gropius, W. "Grundsätze der Bauhausproduktion." In Neue Arbeiten der Bauhauswerkstätten. Edited by W. Gropius and L. Moholy-Nagy. Bauhausbücher 7. Munich: Langen, 1925, pp. 5-8.

7. Nerdinger, W. "Zwischen Kunst und Klassenkampf. Positionen des Funktionalismus der zwanziger Jahre." In Architektur: Macht: Erinnerung. Edited by W. Nerdinger, C. Hölz and R. Prinz. Munich: Prestel, 2004, pp. 43-57.

8. Von Moos, S. "Im Vorzimmer des 'Machine Age'." In L'Esprit Nouveau: Le Corbusier und die Industrie 1920-1925. Edited by S. von Moos. Berlin: Ernst \& Sohn, 1987, pp. 12-25.

9. Hughes, T. “Appel aux Industriels." In L'Esprit Nouveau: Le Corbusier und die Industrie 1920-1925. Edited by S. von Moos. Berlin: Ernst \& Sohn, 1987, pp. 26-31.

10. Reichlin, B. "Solution élégante." In Le Corbusier: Une encyclopédie. Edited by J. Lucan. Paris: Centre Pompidou, 1987, pp. 369-77. 
11. Bittner, R., H. Brüning, G. Fehl, and H. Kegler. Zukunft aus Amerika: Fordismus in der Zwischenkriegszeit. Berlin: Stiftung Bauhaus Dessau and RWTH Aachen, 1995.

12. Gropius, W. Bauhausbauten Dessau. Bauhausbücher 12. Munich: Langen, 1930.

13. Nerdinger, W. “Walter Gropius-Vom Amerikanismus zur Neuen Welt.” In Der Architekt Walter Gropius. Edited by W. Nerdinger. Berlin: Gebrüder Mann, 1985, pp. 9-32.

14. Klein, A. “Beiträge zur Wohnungsfrage.” In Probleme des Bauens: Der Wohnbau. Edited by F. Block. Potsdam: Müller \& Kiepenheuer, 1928, pp. 116-45.

15. Klotz, H. Ernst May und das Neue Frankfurt 1925-1930. Berlin: Ernst \& Sohn, 1986.

16. Allmayer-Beck, R. "Zusammenhänge zwischen Wohnungsbau und Rationalisierung der Hauswirtschaft anhand der Küchenplanungen von Margarete Schütte-Lihotzky." In Margarete Schütte-Lihotzky: Soziale Architektur: Zeitzeugin eines Jahrhunderts. Edited by P. Noever. Wien, Köln and Weimar: Böhlau, 1993, pp. 235-46.

17. Giedion, S. Befreites Wohnen. Zürich: Orell Füssli, 1929.

18. Vetter, A. Die Befreiung des Wohnens. Ein Architekturphänomen der 20er und 30er Jahre. Tübingen and Berlin: Wasmuth, 2000.

19. Steinmann, M. CIAM. Internationale Kongresse für Neues Bauen. Congrès Internationaux d'Architecture Moderne. Dokumente 1928-1939. Basel and Stuttgart: Birkhäuser, 1979.

20. Klotz, H. “Das Pathos des Funktionalismus.” Archithese 3 (1977): 3-4, 22.

21. Borrmann, N. 'Kulturbolschewismus' oder 'Ewige Ordnung'. Architektur und Ideologie im 20. Jahrhundert. Graz: Ares, 2009.

22. Teige, K. K Sociologii Architektury. Praha: Odeon, 1930.

23. Cohen, J.-L. "Introduction." In Modern Architecture in Czechoslovakia and Other Writings. Edited by K. Teige. Los Angeles: Getty Research Institute, 2000, pp. 1-55.

24. Eisen, M. Vom Ledigenheim zum Boardinghouse: Bautypologie und Gesellschaftstheorie bis zum Ende der Weimarer Republik. Berlin: Gebrüder Mann, 2012.

25. Nerdinger, W. “'Anstößiges Rot'. Hannes Meyer und der linke Baufunktionalismus. Ein verdrängtes Kapitel Architekturgeschichte." In Geschichte: Macht: Architektur. Edited by W. Oechslin. Munich: Prestel, 2012, pp. 128-47.

26. Noever, P., and B. Groys. Tyrannei des Schönen. Architektur der Stalin-Zeit. Munich: Prestel, 1994.

27. Isaacs, R. Walter Gropius. Der Mensch und sein Werk. Frankfurt am Main and Berlin: Ullstein, 1986, vol. II/1.

28. Behne, A. Der Moderne Zweckbau. Munich: Drei Masken, 1926.

29. Bletter, R. H. "Introduction." In The Modern Functional Building. Edited by A. Behne. Santa Monica: Getty Research Institute, 1996, pp. 1-83.

30. Le Corbusier. “Prefazione alla prima edizione." In Gli Elementi Dell'Architettura Funzionale: Sintesi Panoramica Dell'Architettura Moderna. Edited by A. Sartoris. Milano: Hoepli, 1932, pp. 9-10.

31. Rudberg, E. "Svensk funktionalism." In Nordisk Funktionalism. Arkitektur, Arkkitehti, Byggekunst and Arkitekten. Edited by G. Lundahl. Stockholm: Arkitektur Förlag, 1980, pp. 116-21.

32. Henze, V. Das Schwedische Volksheim. Zur Struktur und Funktion Eines Politischen Ordnungsmodells. Florence and Berlin: European University Institute, Florence, Humboldt-Universität zu Berlin, 1999.

(C) 2017 by the author; licensee MDPI, Basel, Switzerland. This article is an open access article distributed under the terms and conditions of the Creative Commons Attribution (CC-BY) license (http://creativecommons.org/licenses/by/4.0/). 